\title{
Research for the Marketing State in Russian Museums
}

\author{
Sidorchuk Roman Roaljdovich ${ }^{1} \&$ Grineva Olga ${ }^{1}$ \\ ${ }^{1}$ Department of Marketing, Plekhanov Russian University of Economics, Moscow, Russian Federation \\ Correspondence: Sidorchuk Roman Roaljdovich, 306, 62-19, Novoslobodskaya st., Moscow, 127055, Russian \\ Federation. Tel: 7-926-218-1916. E-mail: sidorchuk-roman_m@mail.ru
}

\author{
Received: October 15, 2014 Accepted: November 5, 2014 Online Published: November 20, 2014 \\ doi:10.5539/res.v6n4p283 URL: http://dx.doi.org/10.5539/res.v6n4p283
}

\begin{abstract}
The paper presents the results of research on the implementation of the marketing function in museums. The interest in marketing activities in Russian museums is constantly growing. At the same time, there are difficulties associated with the implementation of the marketing function in the organizational activity of museums. The research comprises of semi-structured interviews and a questionnaire survey of directors and heads of departments in museums. The obtained results demonstrate that the marketing function is ineffectively implemented in the activity of museums. Marketing is episodic. Marketing functions are distributed among the employees having no necessary qualification. Marketing tools are limited to certain communicative tools only. Museum officials are aware of the lack of marketing qualification and are interested in enriching marketing awareness of the museum workers. According to museum officials, the main method for increasing the marketing effect in museums is in attracting skilled marketing experts and financial resources for marketing activities. The measures to improve the effectiveness of marketing activities of museums were offered based on the obtained results.
\end{abstract}

Keywords: museum marketing, marketing researches in museums, functions of marketing, non-commercial marketing, organizing marketing in a museum, museum product, pricing in museums, promoting museum service

\section{Introduction}

A contemporary museum is a complex multi-stage system combining leisure with selection, restoration, storage, and exhibition of historical and cultural values, scientific and educational activities. International non-governmental professional organization of the International Council of Museums (ICOM) defines a museum as "a non-profit, permanent institution in the service of society and its development, open to the public, which acquires, conserves, researches, communicates, and exhibits objects of tangible and intangible heritage of humanity and its environment for the goals of education, study and enjoyment". Since the 90's of the 20th century, museums have come to recognizing themselves as a part of the entertainment industry (Anderson, 2004). Under these conditions, museums are in a competitive environment, not only with other museums, but also with suppliers of a wide range of entertainment, educational and recreational services (Rentschler \& Hede, 2007; Sandell \& Janes, 2007; Kotler et al., 2008). Such competition puts museums in tough conditions and affects their funding. Reduced funding of museums is often associated with their economic and informational efficiency. At the same time, museums, as a number of institutions in the field of culture, focus their efforts only on communications among all the diversity of marketing (Sidorchuk \& Grineva, 2013). Russian museums started to demonstrate interest in marketing only in the last few years.

\section{Literature Review}

Marketing in non-profit organizations and museums as their part has its own distinctive features. (Sargeant, 2009) Some researches (Frey, 1998) attempted to explain why a number of museums are engines of the economy of cities, while others just spend public funds. Therefore, in the fight for the financing, the museum officials have to use marketing tools to attract visitors and incorporate marketing into their organizational strategies (Rentschler, 2002). At the same time, the organization of marketing activity hardly finds its place in the daily management activities of the officials of museums. The officials of museums are often sceptical about the usefulness of marketing (Kolb, 2000). The literature and practice provide numerous opportunities in the field of museum products, communications policy, which allows attracting visitors by making a museum an object for personal 
connections (Hausmann, 2012). Museum marketers could just observe the consumers behaviour within museum for understanding their needs (Wallace, 2010). And a lot of useful for museum marketers information could give museum non-visitors, they are rare point of interest of museum researchers (Shola, 2013). Visitors experience studies are another important source of information about visitors expectations and their satisfaction (Falk, 2009). Kotler et al. (2008) traces the various stages of the fund-raising technology development: starting from the initial "begging" to the point where museums and sponsors work together on the museum development projects. There is no doubt that a better marketing requires a strategic approach to the organization of marketing activity in the museum. The issue of forming marketing strategies for non-profit organizations is considered in the literature in different contexts. The peculiarity of this problem for museums is connected with the necessity of combining financial and non-financial aspects while forming marketing strategy (Mottner \& Ford, 2005). Marketing in Russia has been used since the times of the Soviet Union. (Fox, Skorobogatykh, \& Saginova, 2008). The first monography on the theme of non-profits marketing was published in Russia in 2000 (Andreev, 2000).

\section{Methodology}

Our research is focused on the analysis of the marketing functioning in modern Russian museums. It is designed to identify the problems of the officials and employees of museums when performing the marketing tasks. The first semi-structured survey within the scope of the exhibition "Intermuseum 2014" held in Moscow from $4^{\text {th }}$ to $9^{\text {th }}$ of June 2014, enabled us to make the following assumption: Assumption 1: The organization of marketing activities in the majority of Russian museums is non-formalized. At the same time, in modern conditions, the management of museums have a practical necessity to provide solution of tasks that traditionally belong to marketing. There is an understanding that it is required to find ways to maintain the balance between the traditional mission of a museum and its orientation to visitors' demands, in circumstances where the personality of a museum guide is one of the main elements in the processes of marketing communication. (Dorovenchik, 2014). This thesis allows making the following assumption: Assumption 2: the marketing function in museums is performed by the employees without special marketing education. The marketing functions are quite good described in the literature (Kotler et al., 2008), but Rudchenko (2013) notes that Russian museums require the shift from simple sales of museum services having already become traditional to the development of new products and services addressing the demand of modern visitors. In this regard, we made the following assumption: Assumption 3: Russian museums have problems in the performance of the marketing functions.

The research used quantitative and qualitative approaches. Since such a research of Russian museums was conducted for the first time, the researchers found it necessary to start with a qualitative research, which was implemented in the form of in-depth semi-structured interviews with museum representatives. The assumptions of the research were specified at this stage.

The quantitative stage of the research was conducted in the form of a questionnaire survey for the officials and employees of museums. General amount was presented by museum institutions in Russia, and the respondents were the officials and employees of these museums. The feature of the sampling is connected with the fact that the survey was conducted only among the respondents who by their activity supervise or participate in the implementation of the marketing functions of museums. This fact allows considering this survey as a survey of experts (Sidorchuk, 2009). The selection of respondents was based on the "snowball" method (Golubkov,1998). The sampling size is 77 respondents. We did not target gender, age or another (except for the above-mentioned requirements) representativeness of the sampling. The questionnaire consisted of 21 questions, 20 of which were closed. The questioning was carried out by inviting experts to participate in the research. The questionnaire for the survey was posted on such Internet services as www.anketolog.ru, www.survio.com.

It should be noted that the limits of our research are associated with the inability to use a random sampling method. This fact has limited the relevance of the results due to the inability of extrapolation of these data to the entire number of Russian museums.

\section{Results}

The qualitative phase of the research included three in-depth interviews, the participants of which were: the head of a Moscow museum, the expert on museum marketing, the head of PR department of a Moscow museum.

Based on the carried interviews, we can conclude that the administration of museums has no clear understanding of the functions and purpose of marketing. Thus, one of the experts noted, "the officials of museums treat any marketing project with suspicion". In practice, the concept of marketing is replaced by one of the components of the communication complex - "the public relations", which is often a point to stop for the museums. Usually, they do not include other elements of the marketing complex to the development plan, e.g. the museum product, pricing, distribution channels for the museum product, which also need careful elaboration. 
During the interview, the experts noted that in most cases, the museums cannot create the marketing department for one or another reason (budget deficit, lack of qualified employees, etc.). In this regard, the marketing functions are delegated to the employees from other areas of activity, who fail to cope with the tasks in full, since they do not have the appropriate qualifications and skills. The required knowledge is obtained using cut and try method, and in some cases, it is a factor to reinforce distrust towards marketing, as the cost of such tries is covered from the budget of museums.

However, there are employees who know and understand how marketing functions. They try to apply their knowledge in practice, but, unfortunately, this gained experience is not recorded and exchanged between the employees. Each employee responsible for a new project has to pass all the stages once again, making the same mistakes as the fellow predecessors.

An important challenge identified in the course of in-depth interviews, became the gap between the activity of museums and the real needs of the target audience: the demand of events is determined after this event, based on the number of visitors and their feedbacks. The absence of preliminary researches has the negative impact on the activity of museums - some of the exhibitions are non-demanded.

The experts pointed out that there is a problem with the involvement of the youth audience in museums. The competition in this segment is provided by movie theatres, sporting events, and musical shows. The amount of free time of almost all target audiences including young people, decreases. That is why the qualifications of museums employees developing museum products for the youth shall not be inferior to the qualifications of marketing experts on the commercial sector.

Another problem of museums is insufficiently unleashed potential of partnerships with other museums, public sector, and commercial organizations. Joint projects allow the possibility of multiple increase in the museum product, may provide additional funding of socially important exhibitions, attract the corporate segment into museums through business conferences, celebrations, and museum researches support.

The experts underlined the importance of engaging all of the employees into marketing activities, as a small effort of one person leads to greater joint successes. Consumer loyalty is formed based on the impressions received in each of the points of interaction with the visitor. The overall perception of a consumer is affected by the atmosphere and quality of service in the exhibition halls, canteens, wardrobes, and behaviour of the officials and academic employees. Negative impression obtained in one of the points of interaction, will lead to lower overall customer loyalty. The marketing strategy shall be seen by every museum employee as a philosophy and a concept accompanying the daily activity.

In turn, the results of quantitative research demonstrated that only in $50 \%$ of Russian museums the marketing activity is formalized in the form of a special organizational structure - the marketing department. This result largely confirms the assumption 1 developed by the authors.

The respondents noted that the basis for making decisions at the organization of exhibitions and displays are own expert opinion of the museum employees and analysis of experience of other museums. There are almost no researched dedicated to examination of consumer demand. The most common method is to survey visitors who already visited the exhibition or who came to a new exhibition (67\% of respondents). This result confirms the assumption 3 , since the analysis of consumers, their values and their subsequent segmentation are a critical task of marketing.

The respondents attributed the underdevelopment of marketing in museums with the lack of resources (Figure 1). 


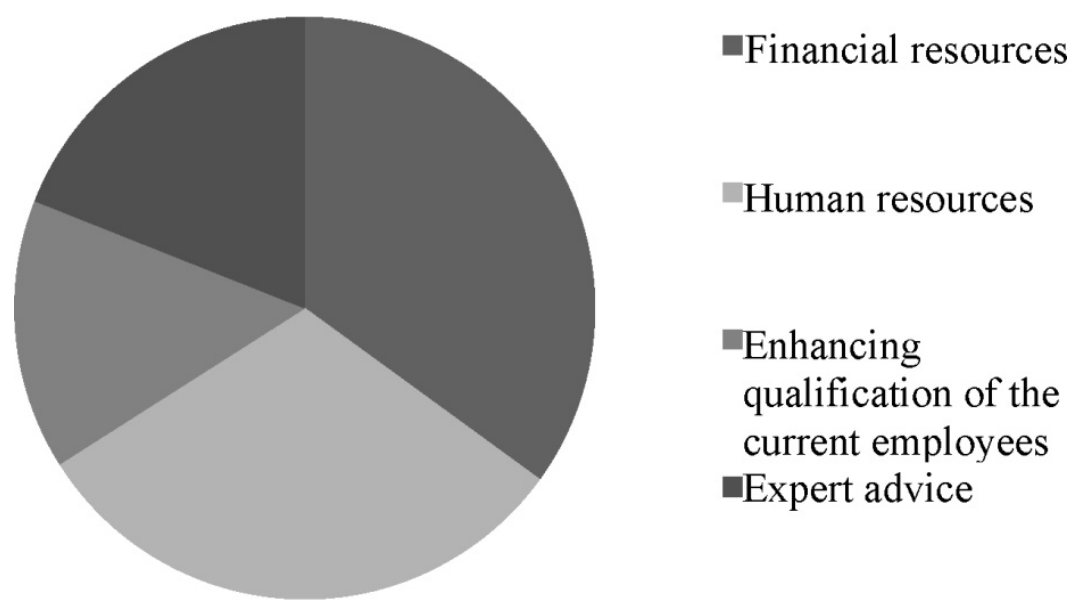

Figure 1. Additional resources required by museums for the marketing function implementation

First, this includes:

1) Financial resources. Money on marketing is primarily allocated under the plan or as required;

2) Human resources (qualified marketing employees). It should be noted that the unemployment rate in Russia as of January 2014 comprised 5.6\%, and as of July 2014 fell to 4.9\%. In large cities, the unemployment rate is significantly lower, for example, in Moscow it comprises 1.5\%. (Labour resources, 2014). In these circumstances, the employers shall make special efforts to attract qualified employees. Distribution of marketing functions increases the employees' job load of other departments. In addition, their performance of marketing functions without additional training leads to a reduction in the quality of other employees' work. This confirms the assumption 2 developed by the authors.

Despite the fact that the certain steps on management and formalization of marketing activities are taken, and according to respondents, the assessment of the implementation of the marketing function in museums is insufficient. Only $17 \%$ of respondents are willing to recognize the marketing activities as effective; $66 \%$ of respondents believe that marketing is the area for development; $17 \%$ of the employees believe that the marketing in their museum is ineffective.

The research revealed the interest in obtaining marketing skills by the museums employees-all the respondents recognized the need for additional knowledge (Figure 2).

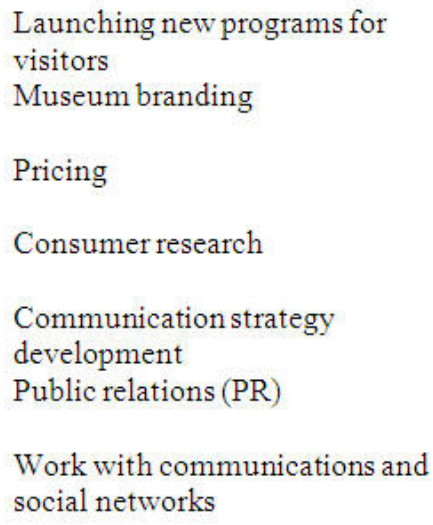

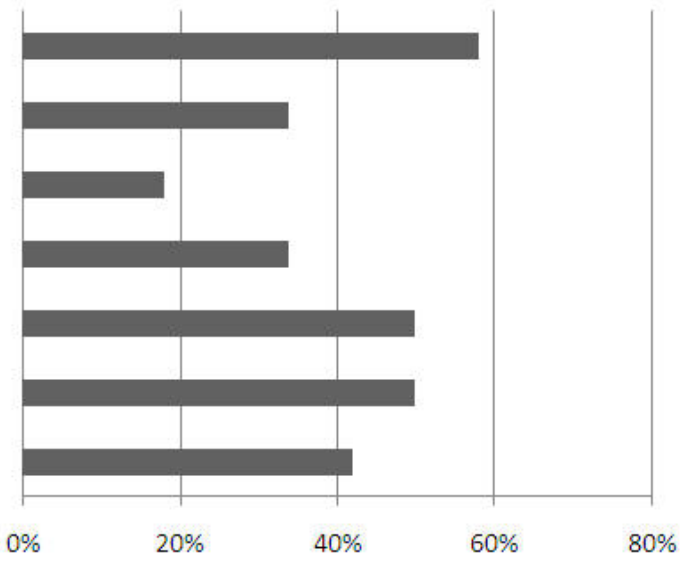

Figure 2. Employees need to obtain special knowledge

The respondents believe that the knowledge on launching the new programs for visitors is the most relevant, while knowledge on pricing is the least relevant. This is explained by the fact that the museum employees perceive pricing only as a procedure of appointing the price of entry tickets and refer it to the question to be decided centrally at the level of the Ministry of Culture of Russia. Simultaneously, the marketing approach to pricing is a differentiation of income sources, analysis of consumer values, and determination of the 
corresponding price of a visit to a museum.

Taking into account that museums face the challenges of ensuring the growth of extra-budgetary revenue, the questions of the target audiences need analysis and marketing pricing may become the key factors for success in this challenge.

During the survey, the following comments were received from the respondents: "We are making a marketing department, because there was an order from top management" or "It is not necessary to chase for the number of visitors. What is more important is to make good exhibits". All of these answers point to the fact that the museum community does not adequately realize the place of marketing in museum management and its contribution to creation of "good" exhibitions yet. This may be because the majority of the officials and employees of museums have no clear understanding of the "museum marketing" concept. According to $24 \%$ of the respondents, PR and advertising fit the definition of "museum marketing" better (Figure 3).

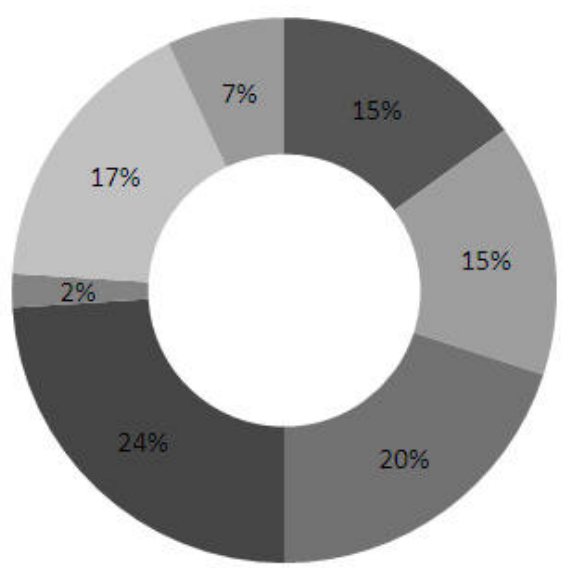

\author{
-Strategic \\ management of \\ museum activity \\ Pricing \\ -Marketing researches \\ -Public relations (PR), \\ advertisement
}

Figure 3. "Museum marketing" concept components

The results showed that the majority of museums $(67 \%)$ have programs to attract sponsors, but their effectiveness in $25 \%$ of cases in doubtful.

During the analysis of the relationship between the variables of the research, it was revealed that in $83 \%$ of cases, missing marketing department leads to the fact that the museum employees see the carried marketing efforts as ineffective. The respondents in museums carrying out no surveys of visitors on their satisfaction with the current exhibits, consider museum marketing as ineffective. The following pattern was detected: $70 \%$ of employees of museums having a marketing department, are aware of the level of annual attendance of the museum. The respondents in museums having no marketing department, did not have such awareness.

\title{
5. Conclusions
}

The obtained results allowed formulation of the following conclusions and recommendations. Now, many officials and employees of museums do not consider marketing as a part of the management processes and do not perceive museums as a competitor for visitors' leisure.

The research results suggest that the marketing function is ineffectively implemented in the activity of museums. Museum employees mostly perceive marketing limited to such 4P element as the promotion-i.e. PR, advertising, and branding. The analysis of the demand for the planned exhibits and displays is not carried out. There is no analysis of the target audience, values of visitors, and their segmentation. Quite popular is the evaluation of visitors' satisfaction, who have already come to the exhibition, as well as forecasting of the future success of exhibitions based on previous surveys.

According to the authors of the research, the problems in the implementation of the marketing function in museums is not that much in the formalization of the organizational marketing structure but in the qualification of the employees responsible for marketing. Enhancing the skills of the existing personnel will provide a holistic understanding of the purpose of the marketing function in museums. 
The research revealed the interest of employees in getting special knowledge in the field of marketing. The employees see the main method for enhancing the effectiveness of marketing in the museum in attraction of financial and human resources.

Professional advice on marketing shall be considered as the important resource for enhancing qualification in the field of marketing and for meeting current marketing objectives. This cooperation leads to the increased awareness and competence of the officials and employees of museums in the field of marketing.

Another way to enhance the marketing awareness of the officials and employees of museums the authors see in the formation of the joint knowledge base and system for experience exchanges in the field of museum marketing.

One of the steps to improve the effectiveness of marketing activities in museums can be cooperation with universities preparing specialists in marketing. This interaction may have long-term benefits in several strategic areas of museums activity:

1) Museums can get assistance in conducting research and solving the tactical marketing issues including assistance of highly qualified teachers,

2) Museums employees will be able to increase their level of knowledge on marketing in projects aimed at improving functioning of museums, in accordance with the concept of "learning by doing".

3) University students can get acquainted with a new area for application of marketing knowledge and continue their activity as employees of museums marketing departments thus making up the shortage of qualified employees. Taking into account the data on unemployment, students and graduates of Russian universities do not have any problems in finding a job. Employers need to make special efforts to attract university graduates.

The authors suggest the need for further quantitative studies of museums officials opinions. With new surveys, the authors see the need to change the approach to sampling and to expand the scope of cooperation with museums.

\section{Acknowledgements}

The authors of the paper would like to thank all the people and organizations having facilitated this research. First, the authors thank Professor Grishin, V. I., the rector of the Plekhanov Russian University of Economics, for the grant given for the research. The authors also thank Professor Andreyev, S.N., for his guidelines at the organization of the survey. Special thanks from the authors are to Alexeyeva, I. B., the deputy director for scientific and educational work of the State Historical Museum and Kornoukhova, I. A., lyceum curator of the State Historical Museum for their assistance in conducting the research and organizing the conference on the presentation of the results.

\section{References}

Anderson, G. (Ed.). (2004). Reinventing the museum: Historical and contemporary perspectives on the paradigm shift. Walnut Creek CA: Altamira.

Andreev, S. N., \& Melnichenko, L. N. (2000). Non-profits marketing basics. Moscow: Progress-Traditsiya.

Dorovenchik, E. I. (2014). Methods of effective communication in museum visits, Balandinskie reading, 1 , 438-445.

Falk, J. H. (2009). Identity and the Museum Visitor Experience. California, Left Coast Press.

Frey, B. (1998). Superstar Museums: An Economic Analysis. Journal of Cultural Economics, 22(2/3), 113-125. http://dx.doi.org/10.1023/A:1007501918099

Fox, K. F. A., Skorobogatykh, I. I., \& Saginova, O. V. (2008). Philip Kotler's influence in the Soviet Union and Russia, European Business Review, 2, 152-176. http://dx.doi.org/10.1108/09555340810858298

Golubkov, Y. P. (1998). Marketing Studies. Moscow: FINPRESS.

Hausmann, A. (2012). The importance of word of mouth for museums: an analytical framework. International Journalf Arts Management, 14(3), 32-43.

ICOM. (2014). Museum Definition. Retrieved from http:/icom.museum/the-vision/museum-definition/

Kotler, N., Kotler, P., \& Kotler, W. (2008). Museums Marketing and Strategy (2nd ed.). San Francisco: Wiley.

Kolb, B. M. (2000). Marketing cultural organisations: New strategies for attracting audiences to classical music, dance, museums, theatre and opera. Oak Tree Press: Dublin. 
Labour $\quad$ (2014). http://www.gks.ru/wps/wcm/connect/rosstat_main/rosstat $/$ ru/statistics/wages/labour_force

Mottner, S., \& Ford, B. J. (2005). Measuring non-profit marketing strategy performance: The case of museum stores Journal of Business Research, 58, 829-840. http://dx.doi.org/10.1016/j.jbusres.2003.06.004

Rentschler, R., \& Hede, A.-M. (2007). Museum Marketing: Competing in the Global Marketplace. Burlington, MA: Elsevier.

Rentschler, R. (2002). Museums and performing arts marketing: The age of discovery. Journal of Arts Management, Law and Society, 32(1), 7-14. http://dx.doi.org/10.1080/10632920209597330

Rudchenko, V. N. (2013). Specific features of social marketing on the museum complex example. Petersburg economic journal, 1(1), 18-24.

Sandell, R., \& Janes, R. R. (Eds.). (2007). Museum Management and Marketing. Abingdon, UK: Taylor \& Francis.

Sidorchuk, R. R., \& Grineva, O. O. (2013). Communication Strategy Verkhoturye as a tourist center of the Urals, $V$-th International scientific-practical conference: Modern Economy: Concept and model of innovative development (pp. 382-386). Moscow, Russia: Plekhanov Russian University of Economics.

Sargeant, A. (2009). Marketing management for non-profit organizations (3rd ed.). Oxford, UK.: OUP.

Shola, T. (2013). Eternity doesn't live here anymore. Tula, "Yasnaya Polyana" Publishing House.

Sidorchuk, R. R. (2009). Fundamentals of management consulting, Marketing approach (p. 220). Moscow, "Sputnik +".

Wallace, M. A. (2010). Consumer research for museum marketers: Audience insights money can't buy. Maryland, AltaMira Press.

\section{Copyrights}

Copyright for this article is retained by the authors, with first publication rights granted to the journal.

This is an open-access article distributed under the terms and conditions of the Creative Commons Attribution license (http://creativecommons.org/licenses/by/3.0/). 